See discussions, stats, and author profiles for this publication at: https://www.researchgate.net/publication/273128862

\title{
Towards an Understanding of How School Administrative Clerk's Negotiate Their Work in Public Schools: A Social Worlds Perspective
}

Article in International Journal of Educational Sciences · February 2015

DOI: 10.1080/09751122.2015.11890251

CITATIONS

2

3 authors, including:

Abdullah Bayat

University of the Western Cape

17 PUBLICATIONS 84 CITATIONS

SEE PROFILE
READS

421

Visvanathan Naicker

University of the Western Cape

11 PUBLICATIONS 58 CITATIONS

SEE PROFILE

Some of the authors of this publication are also working on these related projects: 